\title{
Does the entrepreneurial state crowd out entrepreneurship?
}

\author{
David B. Audretsch • Antje Fiedler ${ }^{(D)}$
}

Accepted: 4 January 2022 / Published online: 23 February 2022

(C) The Author(s) 2022

\begin{abstract}
This paper argues that an entrepreneurial state can inadvertently crowd out entrepreneurship. Using the context provided by Singapore, the paper finds that coordinated policies that prioritize and target capital, knowledge, and human capital accumulation in particular industries, sectors, technologies, and firms have created a formidable societal knowledge filter, which in turn can impede endogenous entrepreneurial activity. By serving as the entrepreneur, Singapore's entrepreneurial state imposes its vision by assuming the core entrepreneurial values and traits of opportunity recognition, discovery, and action. The entrepreneurial state, at least in the case of Singapore, retards the transition to an entrepreneurial society, which, paradoxically, is the vision of Singapore's entrepreneurial state.
\end{abstract}

Plain English Summary States increasingly engage in entrepreneurial activities. This paper explains how the policies and activities of such entrepreneurial states may inadvertently create barriers to a more inclusive entrepreneurial society where entrepreneurship

\section{B. Audretsch}

Institute for Development Strategies, Indiana University,

Bloomington, IN, USA

e-mail: daudrets@indiana.edu

A. Fiedler $(\bowtie)$

Management and International Business, University of Auckland, Private Bag 92019, Auckland, New Zealand e-mail: a.fiedler@auckland.ac.nz is embraced by diverse citizens. Drawing on the case of Singapore, this paper shows that it is not the individual state activities in the entrepreneurial sphere, but the mix of activities, which starves entrepreneurship. The article focuses on state activities in the areas of capital, knowledge, and human capital, and shows how such activities jointly have reduced the scope of private entrepreneurial endeavor. In doing so, the article provides knowledge on the relationship between entrepreneurial states and an inclusive entrepreneurial society. It draws attention to the effects of policy configurations and action on entrepreneurship.

Keywords Entrepreneurial state $\cdot$ Entrepreneurial society $\cdot$ Endogenous growth $\cdot$ Exogenous growth . Knowledge filter $\cdot$ Crowding out

JEL Classifications $\quad \mathrm{E} 20 \cdot \mathrm{L} 26 \cdot \mathrm{O} 25 \cdot \mathrm{O} 32 \cdot \mathrm{O} 38 \cdot$ $\mathrm{O} 53$

\section{Introduction}

The scholarly literature on entrepreneurship has had a primary focus on decision-making in the context of the private sector. This is not to say that the entrepreneurship literature is silent on the role of public policy. On the contrary, public policy has been viewed as playing a crucial role in shaping the external context in which entrepreneurial decisions are made. However, while public policy, or what has been widely 
viewed as constituting entrepreneurship policy, could be either more or less conducive to entrepreneurship, the crucial decisions about recognizing, creating, and acting upon opportunities have been left to entrepreneurs outside of the realm of government.

More recently, Mazzucato $(2011,2013)$, in The Entrepreneurial State, posits that entrepreneurial activity in the private sector will actually be enhanced if the locus of decision-making concerning entrepreneurial opportunities and their exploitation is shifted to the government. She goes on to argue (Mazzucato, 2013) that, in fact, the entrepreneurial state is complementary and conducive to entrepreneurship in the private sector. She bolsters her thesis with compelling examples and case studies, largely from the United States (US).

A nuanced, but significant, distinction divides Mazzucato's entrepreneurial state and the traditional view prevalent in the literature regarding entrepreneurship policy. The latter generally characterizes government policy as creating an external context conducive to entrepreneurship. The locus of entrepreneurial decisions is still in the hands of private decisionmakers. An enlightened public policy simply facilitates the ability of private entrepreneurs to create, recognize, and commercialize opportunities through an enhanced external environment more conducive to entrepreneurial activity. In contrast, the entrepreneurial state shifts the locus of that entrepreneurial decision to the state. According to Mazzucato $(2011,2013)$, in the entrepreneurial state key entrepreneurial opportunities are created, discovered, and commercialized or exploited by the government. Entrepreneurial decision-making is internalized within the government in the entrepreneurial state, while for entrepreneurship policy, entrepreneurial decision-making is externalized. Enthusiasm and endorsement for the entrepreneurial state emanate from the premise that the governmental entrepreneurial activity will spill over to ignite entrepreneurship in the broader society, leading to the emergence of an entrepreneurial society.

At the same time, there is evidence showing that expanding the realm of the government can crowd out private enterprise. For example, David et al. (2000) argue that publicly funded R\&D investment can crowd out private R\&D investment by subsidizing projects with high marginal rates of return or by driving up costs for critical input factors for R\&D projects, such as scientific personnel (David et al., 2000). Audretsch et al. (2012) point out that innovative entrepreneurs might be crowded out by public institutions that receive significant taxpayer support towards salaries and laboratories, such as universities. This evidence points towards potentially negative side effects of increasing government activities for entrepreneurship and raises the question of whether the entrepreneurial state might create barriers to an entrepreneurial society by crowding out private enterprise including entrepreneurship.

The purpose of this paper is to challenge the view that the entrepreneurial state is always complementary to entrepreneurial activity in the private sector at large and facilitates an inclusive entrepreneurial society. We do this by following the conclusions of Welter (2011) that context matters by analyzing the impact of the entrepreneurial state on entrepreneurship in the specific context of Singapore. The economies in East Asia, such as Singapore, Taiwan, and South Korea have demonstrated a historical determination to catch up by leveraging the entrepreneurial state (Yu, 1997), which provides a sharp contrast to the priority of private decision-making prevalent in the Western advanced economies, such as the US (Bardhan, 1990). As Kohli (1994) concludes, the entrepreneurial state has fueled impressive rates of growth and economic development in Singapore and elsewhere in East Asia by triggering an "economic miracle" (Yu, 1997).

Singapore exhibits two key aspects rendering it a compelling alternative context to the Western developed countries for analyzing the impact of the entrepreneurial state. The first is its astounding economic development. Since becoming self-governing in 1959 and independent in 1965, Singapore has achieved exceptional economic growth, "averaging $8.25 \%$ per year between 1960 and 1991" (Bruton et al., 2002, p. 198). The tiny city state has been transformed from one of the poorest countries in the world when it gained independence, to a contemporary economic powerhouse, with a standard of living ranking among the world's highest (Prime, 2012).

The second aspect is its apparent success in fueling dynamic entrepreneurship. As Scott (2015) points out in the Harvard Business Review, the entrepreneurial state has enabled Singapore to shift from industrial policies focusing on inward foreign direct investment and the incumbent firms to vital state-sponsored 
innovation hubs, and a flourishing entrepreneurial ecosystem. Specifically, Singapore's entrepreneurial ecosystem was ranked by Startup Genome as the $10^{\text {th }}$ best startup ecosystem in the world in 2015 and the $17^{\text {th }}$ best global startup ecosystem in 2020 (Startup Genome, 2020).

The apparent success of Singapore in its transformation from a managed to an entrepreneurial driven economy has been widely celebrated: "Singapore has become renowned as one of the leading global hotspots for entrepreneurial innovation. It should thus be of little surprise that budding entrepreneurs from around the world are flocking there in huge numbers to benefit from the economic climate there when they launch startups" (Porteous, 2020, para. 1). Similarly, EHL Insights (2021) gushes, "Singapore: where entrepreneurial dreams come true" (para. 2).

Thus, these two aspects of rapid economic development, combined with the widely heralded entrepreneurial success, would seemingly confirm that state entrepreneurship is complementary and conducive to (private sector) entrepreneurship, at least in the East Asian developmental context of Singapore. This paper subjects the entrepreneurial state to theoretical and empirical scrutiny, enabling us to challenge the pervasive perception of, and conclusions on, the efficacy of the entrepreneurial state. Instead, this paper concludes that the entrepreneurial state is a coin with two sides. The other side of the coin is that while shifting the locus of opportunity discovery, recognition, and commercialization to the entrepreneurial state can fuel entrepreneurial activity in certain industries and sectors, it also imposes a societal knowledge filter that ultimately can crowd out entrepreneurship. Thus, the virtues of the entrepreneurial state may be considerably more nuanced and ambiguous than have been considered in the extant literature.

In the second section of the paper, the distinction between entrepreneurship policy and the entrepreneurial state is explained. The third section analyzes how and why the entrepreneurial state has impacted entrepreneurship in the developmental context of Singapore. The implications of our findings about how and why the entrepreneurial state has shaped entrepreneurship are the focus of the fourth section. In particular, this paper finds that contrary to its widely celebrated success, the entrepreneurial state has the potential to actually crowd out (private) entrepreneurship, resulting in a more nuanced and ambiguous assessment of its efficacy.

\section{The entrepreneurial state}

As Shane and Venkataraman (2000) make clear in their seminal paper, entrepreneurship revolves around the recognition, creation, and exploitation of opportunities. The ensuing explosion of literature analyzed how and why individuals, teams of individuals, companies, organizations, and actors within an organization make entrepreneurial decisions. In the extant literature, public policy has generally been viewed as establishing and influencing the external context, or conditions, in which entrepreneurial decisions are made. Through policies concerning finance, bankruptcy, regulations, labor markets, immigration, taxes, zoning, education, infrastructure, training, universities and research, and foreign trade and investment, among others, entrepreneurial decisions could be either enhanced or, alternatively, impeded. The point is, however, that entrepreneurial decisions are made by individuals and organizations outside of the government. Government policy, while influencing entrepreneurship indirectly through its policies and institutions, abstains from entrepreneurship itself. While the context in which entrepreneurial opportunities are created, discovered, and commercialized can be heavily influenced by public policy, they remain in the realm of non-governmental decisionmakers.

The view of government as remaining on the sidelines of entrepreneurship changed radically with the publication of Mazzucato's, 2013 book. Providing compelling historical examples and case studies, largely from the US, she posited that, in fact, what she characterizes as the entrepreneurial state expands its sphere of policies to include those based on a high degree of "Knightian risk" (Mazzucato, 2011, p, 48), which goes considerably beyond the view prevalent in the literature of the government indirectly influencing entrepreneurship through instruments to modify the external context. In particular, building on Schumpeter, she argues the entrepreneurial state is considerably more involved than merely observing or scaffolding innovation from the sidelines through its commitment to become a catalyst for radical innovation and novel ideas (Mazzucato, 2011). 
Thus, the entrepreneurial state not only establishes the rules enabling and governing entrepreneurship, but more directly has skin in the game through its own entrepreneurial decisions and direct involvement and partnerships with private sector actors to develop innovative products and processes (Mazzucato, 2011). The entrepreneurial state differs from public policy in the entrepreneurial society in that the former sets an explicit vision for economic growth (Mazzucato, 2011) while the latter represents a society in which entrepreneurship is inclusive and broad-based, and contributes to or prioritizes economic growth (Audretsch, 2007). The idea that an entrepreneurial state can be a catalyst triggering industry transformation goes back at least to Schumpeter, who argued that temporary state interventions in markets to generate new technologies can enhance industry capabilities, and ultimately advance economic progress in society (Ebner, 2009).

While the link has hardly been considered, an implicit assumption prevails regarding the concordance between the entrepreneurial state and entrepreneurial society. Mazzucato (2016) even goes on to argue that an entrepreneurial society needs an entrepreneurial state to set a vision for entrepreneurs and investors to prioritize desirable growth opportunities for society and actively invest in targeted new technologies with the potential for breakthrough innovations. This is often achieved by coordinating policies within and across different areas. The role of the state in orchestrating policies for economic growth is well established in East Asia, where some entrepreneurial states, including Singapore, have served as the catalyst for growth (He, 2020). Some East Asian economies enjoyed "fast economic growth" (Booth, 1999), and "rapid catch-up growth" (Frankema \& Smits, 2005) vis-à-vis the West (Ebner, 2009). Scholars analyzing the institutional settings conducive to accelerated growth and development might even attribute that to what the World Bank (1993) termed as constituting the "East Asian miracle."

One key explanation underlying the East Asian miracle lies in the institutions created by the state, including an education system focusing on STEM (science, technology, engineering, and mathematics) subjects, government support for science and technology development, and for setting targeted incentives for private investment (Ebner, 2009). In particular, the entrepreneurial state can spur innovation by investing either in unexplored technologies and $\mathrm{R} \& \mathrm{D}$ in industries during the early stages of their lifecycle evolution, when private capital sources often balk at the high uncertainty and risk as characterized by the valley of death (Mazzucato, 2013), or into proven technology to become a fast follower (Mathews et al., 2011).

\section{Towards an entrepreneurial society}

Thinking about enablers of economic growth has shifted. While, post-war, large corporations were considered to be the main drivers, more recently thought leaders in policy prioritize the importance of entrepreneurship as a driver of economic growth (Audretsch, 2007). Audretsch (1995) found that small, entrepreneurial firms access and exploit valuable, as-yet-unutilized knowledge from other organizations, including larger businesses and universities, enabling them to innovate and fuel growth. This influential "Knowledge Spillover Theory of Entrepreneurship" highlights the endogenous nature of entrepreneurial opportunities, which links entrepreneurial opportunities and the knowledge available in a specific organizational context to the new startup, where they are actually commercialized through innovative activity (Audretsch, 2007). The transition to an "entrepreneurial society" is achieved when entrepreneurship becomes the dominant source driving economic growth by widely exploiting the opportunities emanating from a given stock of knowledge (Audretsch, 2007). How the state might either deliberately, unintentionally, or counter-intentionally influence the development of such an entrepreneurial society remains obscure and unexplored. Audretsch (2007) suggests that the state can play an important role in laying the foundation for an entrepreneurial society by considering how policies may support individuals to become more entrepreneurial. It should consider the policy impact on not only existing businesses, but also potential businesses, requiring a broader perspective of how knowledge is utilized in society (Audretsch, 2007); for example, knowledge created by universities (Audretsch, 2014).

An entrepreneurial society requires broad openness to new ideas, avoiding a thick and densely obstructive knowledge filter whereby the current dominant drivers of economic growth, like large businesses, along with suffocating regulations, might undesirably 
constrain which ideas are perceived as being available and worth pursuing (Audretsch, 2007). Entrepreneurship entails perceiving, accessing-and commercializing-opportunities residing in knowledge. Audretsch (2014) defines the knowledge filter "as the barrier or gap between the investment in new knowledge and its commercialization" (pp. 316-317). Overall, an entrepreneurial society requires a more permeable knowledge filter that strains out fewer ideas and opportunities, enabling entrepreneurs to win other stakeholders' support to exploit and advance underutilized knowledge that ultimately drives economic growth.

\section{The Singaporean entrepreneurial state and entrepreneurship}

Japan, South Korea, Taiwan, and Singapore have developed institutional settings over the course of several decades to carry some of the risk associated with accelerated economic development and technological catch-up (Kim, 2012). These governments have deliberately taken a more active role in directing economic policy and became active participants in the evolution of new industries and markets to enable firms to become fast followers (Mathews, 2017). Typically, entrepreneurial states in East Asia have focused on what Mathews et al. (2011) described as fast-moving, capital-intensive sectors with growth potential that allowed them to access "dominant technology" from existing players. The main objective of this strategy was to achieve rapid industrialization and to help firms to learn by engaging in global value chains (Mathews, 2017). However, while the Singaporean state has remained prominent in promoting economic growth, that role has declined elsewhere in East Asia, such as in South Korea and Taiwan (He, 2020; Pereira, 2008). More recently, Singapore's vision has shifted from aiming to achieve exogenous economic growth mainly fueled by foreign multinational corporations' (MNCs) activities, towards a more endogenous growth model utilizing the innovation capabilities of local businesses (Ho et al., 2016). However, local innovative entrepreneurship has remained limited (Low, 2005; Wong et al., 2001) until recently.

Building on Braunerhjelm et al. (2010), we investigate Singapore's policies on major drivers of economic growth; namely, capital, knowledge, and human capital, and the impact of these actions and an underpinning, sometimes explicit, state vision on this society's knowledge filter. We discuss how these policies affected local entrepreneurship and ultimately the progress, or the lack of it, towards an entrepreneurial society.

\subsection{Capital accumulation and the societal knowledge filter}

As noted, the Singaporean entrepreneurial state recognized the opportunity to leverage the inflow of foreign ideas and capital early (Wong, 2011). After gaining independence, Singaporean policy revolved around export-led growth MNCs, which were initially attracted by the relatively low wages in Singapore, enabling them to produce labor-intensive products for exporting (Koh \& Kong, 2021). From 1970 to 1980, the state focused on developing targeted industry clusters to stimulate technology transfer from foreign MNCs, enabling local small-to-medium sized enterprises (SMEs) to serve as subcontractors for these MNCs (Koh \& Kong, 2021). Prime (2012) explains that the Singaporean state continued to attract foreign direct income (FDI) thanks to a combination of horizontal policies, such as establishing business-friendly institutions and providing relevant skills through targeted education and training, and macroeconomic policies, such as low inflation. Additionally, the state prioritized policies to stimulate technology development (Prime, 2012).

Another early step to further develop this opportunity in capital accumulation in key industries was an active role by the Singaporean state in enabling industrialization by establishing government-led companies (GLCs) having at least a 20\% direct or indirect government stake (Choo, 2005). Choo (2005) argues that GLCs erect barriers to creativity, as their strong market influence deters entrepreneurial opportunities in the private sector for both investors and local entrepreneurs.

Growth capital for local businesses is still unevenly distributed. Singapore's financial sector was characterized in 2004 as "relatively advanced" (Wang \& Ang, 2004), and some years later, government finance was classified as "plentiful" (Prime, 2012). However, in 2012, the share of business credit allocated to SMEs, at $27 \%$, still lagged considerably behind other East Asian economies, such as Taiwan (50\%) and 
South Korea (76\%) (Monetary Authority of Singapore, 2013). According to the ADB Asia SME Monitor (2020), total loans to SMEs accounted for $15.1 \%$ of gross domestic product (GDP) in 2018.

Moreover, while the state does not provide data on the investment of private investors, such as venture capital, private equity, or angel investors in local SMEs (Monetary Authority of Singapore, 2013), there is evidence that access to private informal SME investment in Singapore has been unevenly available. Specifically, Wong and Ho (2007a) found only 2.4\% of informal SME investors would invest in an entrepreneurial venture without a personal tie with the entrepreneur, leaving very little risk capital available for entrepreneurs through angel investment. A survey by Ghosh et al. (1993) of 101 local Singaporean SMEs identified "shortage of finance" as the thenbiggest perceived challenge faced by local emerging entrepreneurs. It also revealed that entrepreneurs were mainly self-funded, using personal savings $(87.7 \%)$ and/or family loans (40\%) and/or investment by family (Ghosh et al., 1993).

There are pockets where risk capital has been more widely available. In 1983, the venture capital industry was launched in Singapore (Lu \& Hwang, 2010). Funds under management rapidly "gr[ew] from about US\$20 million in 1983 to more than US\$7 billion in 1999" (Bruton et al., 2002. p. 197), until "the size of the VC pool had reached US\$16b in 2004" (Lu \& Hwang, 2010, p. 84). Notably, in 1992, the government established the Venture Capital and Private Equity Association, with the aim of nurturing entrepreneurship in the technology sector (Wonglimpiyarat, 2013).

Most venture capital funds in Singapore are managed by government agencies or companies linked to the state, and are co-funded by the government (Wonglimpiyarat, 2013). Notably, Enterprise Singapore, a state agency, has launched different schemes to facilitate private investment into categories of technology startups, such as Startup SG Equity or SEEDS Capital, where the government co-invests with private investors into tech and deep-tech startups in key sectors, such as health and biomedical sciences, or startups in other emerging technologies, including fintech and artificial intelligence. ${ }^{1}$ Thus, for startups with high international growth potential and solid intellectual property, the Singapore state provides strong support. A National University of Singapore
Entrepreneurship Centre report by Kam et al. (2017) shows that the rate of high-tech startups taking advantage of government support schemes rose dramatically between 2010 and 2017, with a concomitant rise in the participation rate, from 19 to $69 \%$. The same report reveals that private investors, including venture capitalists, are more likely to invest in startups that have participated in such a scheme (Kam et al., 2017). As Wonglimpiyarat (2013) points out, Singapore has also established a formal business angel investment network where startups can receive public co-funding. Overall, the state is de-risking private investment in selected areas through various support mechanisms, including public funding.

In summary, capital in Singapore is still accumulated around large foreign MNCs, GLCs, and increasingly around high-tech startups with the potential either to achieve high international growth, or to create strong intellectual property in newly emerging industries. The support and co-funding to increase growth capital for startups in key industries by the entrepreneurial state effectively de-risks private investment in the high-tech sector and new industries. At the same time, however, as the evidence suggests, the coordinated policies of the entrepreneurial state pose challenges for SMEs outside of the key targeted industries and technologies and operating in peripheral and more traditional sectors.

A consequence of assuming the key entrepreneurial function of recognizing opportunities and creating respective policies has thickened the societal knowledge filter. As a result, funding opportunities for SMEs not eligible for the startup schemes are reduced. Cumming et al. (2021) have pointed out that finance is critical for entrepreneurship, but certain firm characteristics, such as the founder's gender and ethnicity, may influence financing opportunities. Similarly, the entrepreneurial state distorts funding opportunities for SMEs, because strategic support for the selected targeted industries renders funding in areas outside the state's innovation strategy riskier. SMEs operating in traditional industries not only face the full force of free markets but must compete with the targeted high-growth oriented SMEs enjoying preferential treatment by the entrepreneurial state. A wider concern is that proposed new ventures deemed

\footnotetext{
${ }^{1}$ More information can be found at the Enterprise Singapore website, accessible at https://www.enterprisesg.gov.sg/finan cial-assistance/investments\#investments
} 
to be less promising in terms of growth potential and rates of return may never actually be funded and realized, even though some of those ideas might ultimately have resulted in important innovations, but instead are crowded out. Succinctly put, the focus of the entrepreneurial state on de-risking capital accumulation in key targeted industries, technologies, and firms thickens the societal knowledge filter, impeding entrepreneurial opportunities outside of the imposing vision of the state.

\subsection{Knowledge accumulation and the societal knowledge filter}

The Singaporean state was an early mover in recognizing the virtues of becoming a fast follower and upgrading its industrial base by learning through connecting to global value chains. In true fast follower fashion, Singapore's growth vision has prioritized export-led growth (Koh \& Kong, 2021). Attracting large MNCs from abroad provided an avenue for technology and knowledge upgrading, which enabled it to develop significant local information technology and manufacturing capabilities (Wong, 2001). MNCs invested in Singapore for various reasons, including leveraging the city state as a regional service hub, manufacturing, or for R\&D. For the latter in particular, Singapore offered not only a highly skilled local workforce but also government incentives to lure foreign capital (Hu, 2004). These favorable conditions successfully recruited MNCs. After the Asian financial crisis, the government recognized Singapore's vulnerability created by its dependence on foreign capital and knowledge (Yeung, 2000), and increasingly aimed to achieve export-led growth through local business internationalization (Koh \& Kong, 2021). Importantly, in this phase, Singapore recognized the importance of moving towards a "knowledge-based economy" ( $\mathrm{Ng}, 2012)$ and transitioning away from an exogenous towards an endogenous growth model.

There were several key steps enabling Singapore to shift its growth model. First, a key mechanism to transition towards a more innovation-driven society was to lift local innovation capabilities by enhancing local R\&D capacity (Ho et al., 2010; Wang, 2018). In 2012, then, Prime Minister Lee Hsien Loong made it clear that the objective was to better develop more local capabilities in $R \& D$ :
"[O]ur objective is not for the foreign institutions or foreign scientists to do R\&D in Singapore as standalone entities. We want to be something more than just a hotel for R\&D or a pop-up lab [...] We need to [....] groom Singaporeans for leadership positions in research institutes (Prime Minister's Office Singapore, 2012, para. 11-12).”

Until the late 1980s and 1990s, R\&D investment in Singapore remained very low, accounting for only $0.86 \%$ of GDP (Wong et al., 2010). The state started to actively influence innovation activities in Singapore through policy interventions and support for local R\&D (Wang, 2018). Notably, foreign businesses were ineligible for most governmental R\&D support (Wang, 2018), further demonstrating a state vision to shift towards a more endogenous growth model leveraging and utilizing local technological capabilities.

Specifically, to accelerate local entrepreneurship and innovation, Singapore incentivized investment in R\&D, including governmental R\&D. Because R\&D spending of about $2.8 \%$ of GDP in 2008 still lagged other OECD countries, the government committed to boost this to $3.5 \%$ by 2015 (Ng, 2012). Wang (2018) points out that in 2012 , the state financed US $\$ 2.3$ billion R\&D, representing $0.8 \%$ of GDP, which was a full $0.5 \%$ more than the provision of Hong Kong's government in the same year. More recently, Hooi and Wang (2020) argue the public investment into $\mathrm{R} \& \mathrm{D}$ is substantial, with a "ratio of public to private funding [...of] 1:1.5, with government spending at about $1 \%$ of GDP" (p. 163). The state also encouraged private $R \& D$ spending; for example, by offering tax deductions to industry for R\&D expenditure and various grants to build internal technical capabilities (Hooi \& Wang, 2020). By taking a leadership role in knowledge accumulation, Singapore transferred part of the risk of R\&D investment from local companies to the public. Nonetheless, the state's objective to raise total R\&D expenditure as a percentage of GDP over time went unmet. Data from the World Bank (2021) revealed that combined public and private $R \& D$ expenditure as a percentage of GDP actually fell after 2008 from about $2.6 \%$ to about $1.9 \%$ in 2017.

Second, the Singaporean state sought to foster collaboration for $\mathrm{R} \& \mathrm{D}$ and innovation. The intent was to move away from a focus on spillovers from MNCs to local business to a more dynamic enterprise system 
that connects small and large, local and foreign businesses (Prime, 2012), and public research institutions (Hooi \& Wang, 2020) for innovation. Despite the state's vision to encourage more endogenous growth using knowledge produced by local institutions, as Wong (2003, cited in Prime, 2012) points out, technological spillovers still mainly occurred between foreign MNCs and local businesses, while those between either local businesses, or local firms and public research institutions, are less common. There is some evidence that local businesses have learned over time how to exploit knowledge provided by the foreign MNCs. However, they are not using this knowledge to develop independent businesses in new areas or industries, but remain dependent on foreign MNCs. Specifically, they have often embraced business models optimized to serve large foreign MNCs (Wong, 2003, cited in Prime, 2012), including serving MNCs overseas as subcontractors in their internationalization efforts (Dahles, 2002). This suggests that foreign MNCs based in Singapore are still a critical technical knowledge source for local businesses to innovate, and they also generate knowledge spillovers, with the promise of spurring future innovation (Wong \& Ho, 2007b).

In contrast, the contribution of knowledge produced by local business and public institutions to innovation activities has remained small (Wong \& Ho, 2007b), and scholars observe that Singapore's growth model based on exploiting knowledge and R\&D generated by foreign MNCs has crowded out entrepreneurship and local innovation capabilities (Ho et al., 2010; Wang, 2018; Yeung, 2000), just as capital accumulation crowded out funding opportunities. Thus, in knowledge accumulation, the entrepreneurial state has long acted as an orchestrator to attract large MNCs and enable knowledge spillovers for local entrepreneurs, and our investigation suggests that this model is still persistent.

Third, the state had a vision to enable technology entrepreneurship. The state's interest to support technology SMEs had started already in the 1980s (Abeysinghe, 2007, as cited in Klingler-Vidra, 2018). To promote local entrepreneurship in the technology sector, Singapore's state looked to models of different entrepreneurial ecosystems, including Silicon Valley (Klingler-Vidra, 2016). Klingler-Vidra (2016, 2018) provides insights into how Singaporean policymakers were assessing the suitability of the Silicon Valley model, which included a two year stay by K.C. Low, later the manager of the Techopreneurship Investment Fund, in Silicon Valley in 1996-1997. While certain aspects of the Silicon Valley model were appealing, the retreat of the state from the innovation cluster was not aligned with the interventionist approach of the state, and thus neither envisaged nor appreciated. Instead, the state wanted to maintain influence over the model of knowledge accumulation and actively direct the entrepreneurial ecosystem (Klingler-Vidra, 2016, 2018).

In 1999, the state established the National Science and Technology Board, which set up the Technopreneurship 21 program to encourage technology entrepreneurship, and in 2008 launched a national program, namely, the National Framework of Innovation and Enterprise, aiming to enable technology commercialization of public institutes through new ventures (Cheah et al., 2016). The Singaporean entrepreneurial ecosystem emulated some observable features of the Silicon Valley innovation cluster, such as the limited partnership structure, but maintained a strong state influence. (Klingler-Vidra, 2016). The state also actively incentivized foreign knowledge and talent, including MNCs, often with regional headquarters in Singapore, and venture capital investors to play key roles in shaping the ecosystem. (Klingler-Vidra, 2018).

Notably, with regard to local entrepreneurship, after 2003, the state more explicitly urged Singaporeans to engage in innovation-driven activities (Koh $\&$ Kong, 2021). In a keynote address in 2003, the Deputy Prime Minister Lee Hsien Loon reflected a refocus of the state's vision on generating local entrepreneurs that could compete internationally and build a strong knowledge base.

"We needed to rethink all our economic policies and strategies. [...] to prepare Singapore for the transition to a knowledge-based economy. [...] we must promote innovation, creativity, and entrepreneurship. [...] we must deregulate and liberalize the economy, to allow enterprise to flourish. [...] we must encourage self-reliance complemented by community support, and minimize dependence on the state. These ideas emphasize that private enterprise must increasingly lead growth, and that to continue to thrive, we must be willing to venture into the unknown, 
explore new ideas, and establish new enterprises. To succeed, the initiative must come from individuals rather than the state (Monetary Authority of Singapore, 2003)."

However, Klingler-Vidra's studies show that the state maintained a strong directive capacity allowing them to intervene in the development of the ecosystem by "directly financing private sector activity, especially supporting international firms (rather than local)" (Klingler-Vidra, 2018, p. 107).

Overall, Singapore's entrepreneurial state has shifted from "fast follower industrial dynamics" (Mathews et al., 2011, p. 178) "imitating other's innovation" towards a more endogenous growth model promoting entrepreneurship in technology-based sectors, such as biotech (Wong, 2011, p. 8). However, while there has been a clear state mandate to increase innovation capabilities of local entrepreneurs, Singapore's state still relied heavily on foreign MNCs (Carney, 2014; Prime, 2012), as well as foreign talent (Klingler-Vidra, 2018) for innovation activities. Many local businesses have long relied on fast follower industrial dynamics characterized by strong relationships with foreign MNCs rather than having a vision to become a frontier firm. Becoming a frontier firm and absorbing technology from Singaporean-led public research institutions would necessitate different capabilities, as this represents a different type of R\&D (Guellec et al., 2004), and establishing new network relations - often a challenge for smaller businesses. Wong (2011)'s analysis of Singapore's biotech industry revealed that despite the commitment to heavily invest in $R \& D$ relevant to the sector since the 1980s, the economic impact of Singapore's life science sector has been "underwhelming."

To resolve the mismatch by firms changing their business model to become a frontier firm, and their particular approach to innovation, which had proven highly successful in the past, would involve a gamble that decisionmakers on the firm level might not be willing to take. Thus, the state's new vision to foster local frontier technology firms may not match the business realities and internal capabilities of domestic firms. This suggests the mechanism of knowledge accumulation on the firm level might be hard to reshape. By assuming the key entrepreneurial function of opportunity recognition in the area of knowledge accumulation, the entrepreneurial state has created barriers impeding its retreat. As uncertainty remains high, the entrepreneurial state has incentives to build on past success and further commit to a proven state-driven model of knowledge accumulation. In the case of Singapore, the state's past success was built on accessing foreign knowledge and creating a set of policies to exploit it. It is thus not surprising that Singapore is also relying on foreign input when shaping their local innovation system.

Here again, the reliance of external ideas for knowledge accumulation encourages the replication of observable success over the risky pursuit of unproven opportunities. New goals emerge for the entrepreneurial state as knowledge grows. That is, the entrepreneurial state has little indication when goals have been reached in the area of knowledge accumulation as the goals themselves are moving targets. This is likely to lead to an intensification and further coordination of the activities and tighter focus by the entrepreneurial state rather than a phasing out of state interventions, which paradoxically, might be required to foster bona fide endogenous growth. To sum up, past success of knowledge accumulation may create an unwillingness to envisage a clear exit path for the entrepreneurial state, which ultimately thickens the societal knowledge filter.

\subsection{Human capital accumulation and the societal knowledge filter}

In acting as an entrepreneurial state, Singapore makes a strong connection between society's education system and economic growth, stressing that education must remain relevant for industry (Kam \& Gopinathan, 1999), even while also drawing from it for the civil service. Since independence, Singapore has seized the opportunity to transform its education system. The state remarkably moved away from "a poor, unskilled, mostly illiterate workforce" to top of the OECD Program for International Student Assessment rankings in 2016 (Coughlan, 2016). The state sees education as a mechanism to further advance economic growth and development (Gopinathan \& Lee, 2011). Between 1979 and 1996, education concentrated decidedly on mathematics, science, and technical skills, and this was described as the "efficiency-driven phase," whereas the "abilitydriven phase" between 1997 and 2011 encouraged schools to develop more differentiated and innovative 
programs (Tan et al., 2016). The system has nevertheless been criticized as not only overly competitive (Chua \& Bedford, 2016), but also as discouraging critical thinking and creativity and instilling a fear of failure in students that is antithetical to both of these (Choo, 2005). School children were reportedly "deeply depressed and overworked" because of the strict, results-oriented regime (Choo, 2005, p. 369). Research has suggested that certain education settings, such as the university context, can crowd out personality traits that may be critical for entrepreneurial activities (Kolb \& Wagner, 2015). Similar, in Singapore, the state has actively shaped desired traits through the education system, which has created barriers for entrepreneurship.

From 2011 onwards, reforms furnished more opportunities for experiential learning and developing people skills, which combined learning in applied areas such as science, technology and robotics focusing on "big ideas," with programs for "learning for life," such as sports (Tan et al., 2016). Thus, while the education system continues to stress STEM knowledge, a staple foundation of core areas that the entrepreneurial state targets for economic development, recently, it has also included more of the "softer" skills.

Despite the efforts of the state to foster curiosity and innovation in schools, research has shown that students in Singapore are still prioritizing performing well in exams rather than mastering the process of learning (Bedford \& Chua, 2018). Chua and Bedford (2016) point out that the desire to become an entrepreneur is particularly low in Singaporean young adults due to a fear of failure. Entrepreneurship is perceived as a risky career choice that could result in failure, wasted time, and as less desirable than other pathways (Chua \& Bedford, 2016). Similarly, Bedford and Chua (2018) argue that Singapore's youth still have little interest in entrepreneurship because of the risk of failure, which in Singapore is seen not only as financial failure but also as social failure relative to peers and thus is highly stigmatized.

In general, entrepreneurship has had a lower status in society for decades, and employees prefer to work for a large MNC, along with its concomitant higher status. A study in the 1990s of business student graduates disclosed that most would prefer working for an MNC (Teo \& Poon, 1994), and data collected by (Randstad Monitor, 2017) indicate that this is still the case. Entrepreneurship emerged in both studies as a less desirable choice. This evidence reveals a negative effect of FDI, in that potential entrepreneurs are enticed to work for large conglomerates to increase their personal status. Furthermore, domestic entrepreneurs might also feel discouraged by competitive pressures resulting from FDI (Goel, 2018).

Data from the Global Entrepreneurship Monitor report also shows that in Singapore, entrepreneurship on average is stigmatized by a lower social status than in other Asia-Pacific countries. Figure 1 shows the deviation from the Asia-Pacific mean of the Singaporean working age population who give high status to entrepreneurs or consider entrepreneurship as a desirable career choice (between 2003-2006 and 2011-2014). While values fluctuate somewhat in negative territory, at the end of the period, they range around $(-10 \%)$ deviation for the status given to successful entrepreneurs and around (-20\%) for entrepreneurship as a good career choice, respectively.

Similarly, the Startup Genome (2020) provides concerning empirical evidence pointing to the disappointing performance of entrepreneurship in the Singaporean context, such as "knowledge," with a score $2 / 10$ for research measuring the impact of publication based on the H-index. Singapore also scored relatively low with regard to the local market reach $(1 / 10)$ and "quality and access" to tech talent $(2 / 10)$, which includes access to growth employees (employees with at least two years of startup experience). Compared to the report published in 2015 , the availability of entrepreneurial local talent remains relatively weak (Tegos, 2015). Christopher Quek, a community writer for TechinAsia, VC, and a SG Startup Ecosystem evangelist, emphasized several crucial impediments to entrepreneurship in Singapore, including a paucity of a more ambitious vision or big ideas, recognizing global market opportunities, as well as local role models due to very few local startup successes, and a fear of failure (Quek, 2016). Thus, the case of Singapore illustrates how the entrepreneurial state might create both barriers in facilitating local entrepreneurship, even in areas that are strongly supported by the state, and ultimately, an entrepreneurial society.

Meanwhile, the number of attractive opportunities for employment in the entrepreneurial state is rising. To stimulate economic growth, managers of GLCs were also made or deemed entrepreneurs, in that they were rewarded for success with stock options, as the 
Fig. 1 Singapore GEM data: percentage deviation from Asia-Pacific mean

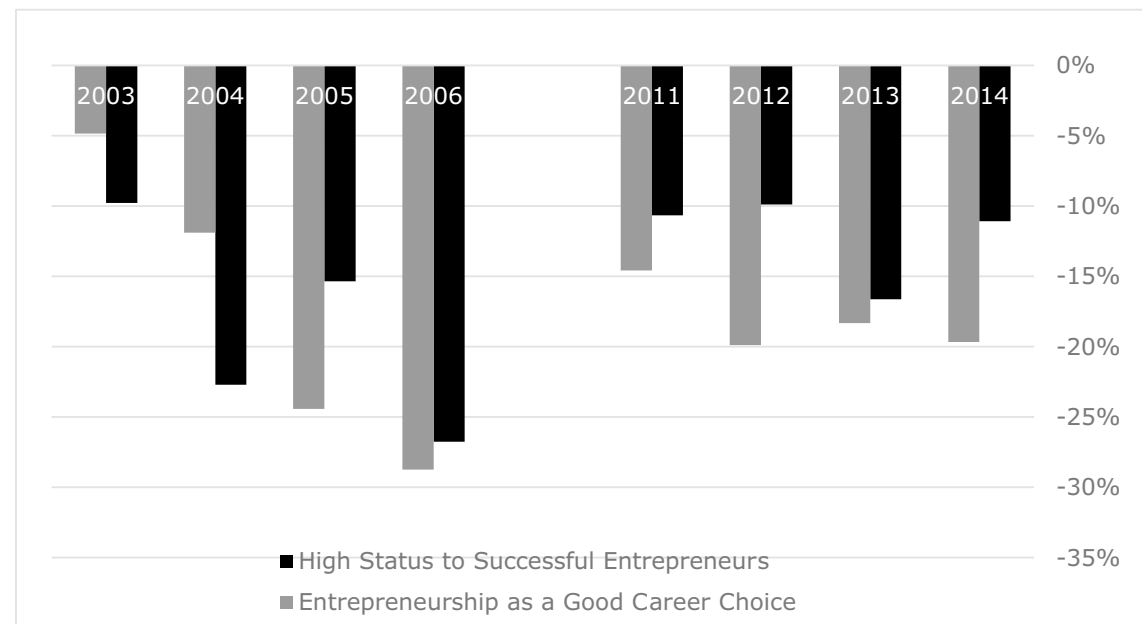

Source: Global Entrepreneurship Monitor (most recent data available until 2014, https://www.gemconsortium.org/economy-profiles/singapore) founding Prime Minister (and the longest-serving: 1959-1990); indeed, Singapore's founding father, Lee Kuan Yew (Choo, 2005), explained in a speech in 2002:

"This was also how GLCs came about. [...] we did not have enough entrepreneurs, and those we had lacked the capital or interest, government ministers undertook the task of starting new ventures. [...] We did it out of necessity $[\ldots]$ selecting the most promising and energetic of our officers to run these new companies. We succeeded. We were fighting to survive. Ministers and senior civil servants were highly motivated with no thought of financial reward. All of us were acutely aware that if we failed the people would suffer unemployment and degradation of their lives. [...] We recognize [...] that we now need to motivate government officers who manage these GLCs by more conventional methods, rewarding them in accordance with the profits they make, including stock options so that they win if the company succeeds (Singapore Government, 2002, para. 16-17)."

While many attribute Singapore's economic success to the leadership of Lee Kuan Yew in pioneering the vision for the entrepreneurial state, concerns have been raised that the majority of the public GLC managers lack entrepreneurial drive and experience, and many of the executive directors of the GLCs are "relatives of senior government officials, current and former government officials, former senior military commanders, and current and former MPs of the ruling PAP.27" (Choo, 2005, p. 367). There is a perception that GLCs received favorable access to capital and tenders, intensifying competitive pressures on markets, which may hurt local private entrepreneurship (Choo, 2005).

Nonetheless, civil servant positions are fiercely competed for. Becoming a government employee is an especially favored career choice for young Singaporeans, who perceive it as "a stable high-paying job with good status that is highly desirable" (Chua $\&$ Bedford, 2016. p. 330). Furthermore, civil servants are recruited by academic merit, and the state had in the past a vision to attract "the best and brightest students into civil service" by offering them attractive scholarships (Choo, 2005, p. 370), stimulating competition among student aspirants. Moreover, the civil sector also recruits talent from the private sector by offering comparable wages and other incentives (Carney, 2014). In this vein, official data from the Department of Statistics Singapore (2021) show that the number of government employees has steadily grown between 2003 and 2018, many of them at senior levels, signaling an even stronger influence of the entrepreneurial state on society (see Fig. 2). Damrich et al. (2022) argue that attractive employment opportunities in the public sector can crowd out private entrepreneurial activities; in particular, those who rely on talented employees critical to develop new knowledge. The evidence from Singapore supports this argument, 
Fig. 2 Employees in Singapore's Civil Service 1965-2018

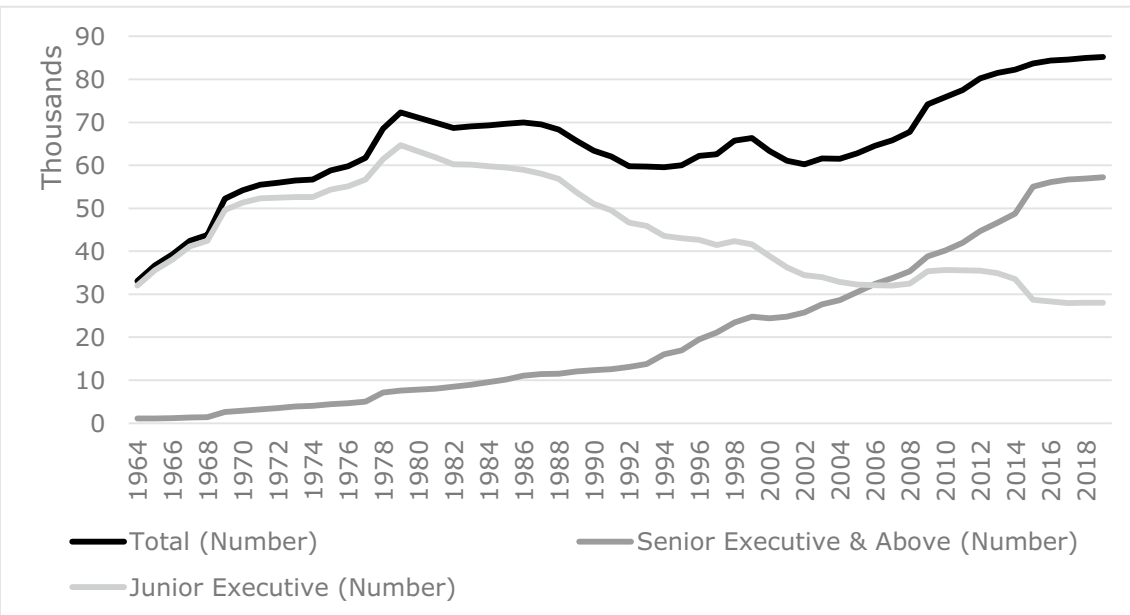

Source: Department of Statistics Singapore (https://www.singstat.gov.sg/) suggesting that talented Singaporeans are drawn to the public sector rather than aspiring to become entrepreneurs.

To encourage entrepreneurship, unicorns are often celebrated as Singapore's success stories; even so, their ideas were influenced by foreign talent. The number of technology startup businesses founded by foreign entrepreneurs in Singapore is not provided by official statistics, neither is the number of visas. However, what is notable is that all six Singaporean unicorns ${ }^{2}$ were either founded (SEA [formerly known as Garena], ${ }^{3}$ Trax, ${ }^{4}$ Grab, ${ }^{5}$ Lazada, ${ }^{6}$ and Patsnap ${ }^{7}$ ) or co-founded $\left(\right.$ Razer $\left.^{8}\right)$ by entrepreneurs with overseas heritage.

\footnotetext{
${ }^{2}$ https://nextunicorn.ventures/the-full-list-of-unicorn-startupsin-southeast-asia/

${ }^{3}$ Garena was founded by Forrest Xiadong $\mathrm{Li}$, who was born in China and holds degrees from Shanghai Jiaotong University and Stanford Graduate School of Business.

${ }_{4}^{4}$ Founded by Dror Feldheim and Joel Bar-El, both ex-Israeli entrepreneurs.

5 Grab was founded in Kuala Lumpur, Malaysia by Anthony Tan, an ex-Malaysian citizen, and Tan Hooi Ling, a Malaysian citizen, who met at Harvard Business School.

${ }^{6}$ Founded by Maximilian Bittner, born and raised in Munich, who holds degrees from University College London and the Kellogg School of Management of the Northwestern University, and Rocket Internet SE (a European company headquartered in Berlin).

7 Jeffrey Tiong was born in Sabah (Malaysia) and holds degrees from National University of Singapore and the Wharton School of the University of Pennsylvania.

${ }^{8}$ Razer, a company dual-headquartered in Irvine (California) and Singapore, was co-founded by Robert Krakoff, an American businessman, and Min-Liang Tan, a Singaporean entrepreneur.
}

Hence, by acting as an entrepreneur and assuming the vision for human capital as well as entrepreneurial human accumulation, the entrepreneurial state may have crowded out individual opportunities for local entrepreneurs. While the Singaporean education system has been celebrated globally as a role model, it also struggles to inspire students to engage in entrepreneurial activities. By serving as the entrepreneur, the Singaporean state sets the vision for society's core entrepreneurial values and attracts the limited young entrepreneurial talent. Overall, even as the state actively tries to shift the perception of entrepreneurship as a desirable career choice, we can observe a path dependency in specialization for human capital accumulation. Thus, innovation activities and entrepreneurship in Singapore remain dependent on input from foreign talent.

\section{Conclusion}

Using the case of Singapore, we have investigated how the entrepreneurial state influences entrepreneurship. Our investigation suggests that the strong entrepreneurial state's vision to foster local entrepreneurship-shaping policies to accumulate capital, knowledge, and human capital paradoxically crowds out entrepreneurship. Rather than spawning an entrepreneurial society, the entrepreneurial state has instead suppressed inclusive entrepreneurship through a suite of policies that thickened the societal knowledge filter in three important ways: first, investors 
favor government-assisted entrepreneurial ventures. Second, knowledge spillovers by Singaporean-led R\&D are not absorbed nearly as easily as those emanating from foreign MNCs, and knowledge is directed through the state to flow to entrepreneurs in high-tech startups, including foreign entrepreneurs, rather than in traditional industries. Finally, the best human capital gravitates to the MNCs or the state itself.

Our investigation of Singapore adds to the debate on how government activities might crowd out entrepreneurship. Unlike previous studies, which have focused on targeted activities of the government to stimulate entrepreneurial growth within society, such as FDI (Goel, 2018) or tax incentives for venture capital financing (Cumming \& MacIntosh, 2006), we assess the effect of governmental policies more holistically in the context of the Singaporean entrepreneurial state. We focused on three key policy areas: capital, knowledge, and human capital, and showed that the entrepreneurial state might inadvertently create a policy accord that crowds out entrepreneurship. Our analysis suggests that policy configurations embraced by the entrepreneurial state rather than individual policies crowd out entrepreneurship, as individual policies interact in redirecting entrepreneurial activity or starving the entrepreneurial spirit. Specifically, our investigation shows that the strong vision and resulting policies of the Singaporean state have unintentionally created a formidable knowledge filter in society, impeding entrepreneurial activity other than in the selected highly preferred high-growth opportunities and creates a liability for developing a heterogenous entrepreneurial society.

First, the thickening of the societal knowledge filter has dissuaded entrepreneurs from engaging in nonlinear, and at times serendipitous, learning processes to create innovative frontier ventures. Entrepreneurship scholars have debated whether targeted public policy focused on high-growth ventures creates the best growth outcome for society. While Shane (2009) believes focused public policy is desirable to foster entrepreneurship, Morris et al. (2015) argue that a portfolio approach that includes diverse and different types of entrepreneurship may create better longterm outcomes. According to Morris et al. (2015), the entrepreneurial process is characterized by trial and error, adaptation, and the emergence of ideas. Failure, initial inefficiencies, and experimentation are part of creating innovative and sustainable ventures
(Morris et al., 2015). Applied to the entrepreneurial society, their argument that breakthrough and more incremental innovation can co-exist, complementing each other, suggests that a wider focus on, and understanding of, entrepreneurship is necessary. Our investigation of Singapore contributes to this debate by demonstrating that targeted policies of the entrepreneurial state have made their citizens' pathway to entrepreneurship narrower as a thickening knowledge filter discourages endogenous growth independent of government support and foreign MNCs.

Second, it appears that the transition from a strong entrepreneurial state towards an entrepreneurial society is costly, with an entrenched entrepreneurial state making a retreat difficult, if not impossible. In Singapore, the strong state directed entrepreneurship by setting the direction in the areas of capital, knowledge, and human capital accumulation, influencing opportunity recognition and action in society. However, ultimately, a strong vision of the entrepreneurial state is incompatible with the requisite freedom conducive to entrepreneurs developing their own entrepreneurial visions. It seems Singaporean society has come to rely on the state to set a vision for future innovation activities and orchestrate growth, and indeed, to provide some of the best career prospects in its own ranks. Existing local businesses are ill-equipped to embrace a new business growth imperative less reliant on powerful actors, at least until they believe its opportunities are commensurate with the status quo reliance on foreign MNCs. Consequently, the thickening of the societal knowledge filter has also created an entrenched state that has become locked in and is unwilling to relinquish its power and control.

Our investigation suggests that the state will further increase its grip on vital knowledge and human capital resources as it struggles to shift from an exogenous towards a more endogenous growth model. Whether this objective can be realized remains uncertain, but there is a risk that greater state involvement in the high growth sector might paradoxically reduce dynamism and also alienate the international MNCs and talent that are currently crucial for knowledge spillovers to fuel local entrepreneurship.

Our analysis suggests that the influence of the entrepreneurial state has over time expanded further, and that an entrenched state, such as Singapore's, has no plan to recede and retreat, either when their objectives of creating an entrepreneurial society are 
achieved, or their efforts are acknowledged to remain beyond its grasp. The lack of a clear exit strategy for the state might suppress entrepreneurial dynamism, and ultimately a retreat of the state is needed for the transition towards an entrepreneurial society.

The contrast provided by the success highlighted by Mazzucato (2013) of the US government in catalyzing the creation of Silicon Valley suggests that the approach and context of the Singaporean entrepreneurial state is strikingly different in two fundamental ways. First, in the US, an endogenous growth model emerged in response to increased entrepreneurial opportunities fueled by a shift to investments in knowledge (Audretsch, 2021). In contrast, in Singapore, the state has latterly aimed to actively encourage a more endogenous growth model, even though their economic growth and success have still relied on utilizing knowledge generated by foreign MNCs (Prime, 2012). In such a context, local entrepreneurs find it harder to attract talent and to compete in industries dominated by large players, including foreign MNCs, and by the government (Choo, 2005; Wang, 2018) as they are crowded out.

Second, while the US government implemented key policies in directing R\&D to become more relevant for entrepreneurship through policy instruments such as the Small Business Innovation Research program and the Bayh-Dole Act, the ensuing entrepreneurship was free of heavy-handed and bureaucratic government direction (Audretsch, 2014, 2021). This hands-off policy approach, in contrast to the entrepreneurial state of Singapore, granted free play for new and unanticipated opportunities to emerge. Thus, the knowledge filter in the US was consequently thinner and less influenced by a very particular vision of the government, which ultimately fueled knowledge spillovers spawning new technologies across a broad range of industries and sectors.

So where does the emergence of such a societal knowledge filter through the vision of the entrepreneurial state leave us regarding the transition to an entrepreneurial society? Policymakers must appreciate the influence of the filter and understand that both state actions and explicit statements communicate a vision which powerfully shapes them. Baumol's (1996) historical analysis has demonstrated that the productive contribution of entrepreneurial activities depends on how much effort in society is devoted towards innovation and productive activity. Using examples from ancient Rome, early China, and medieval and Renaissance Europe, Baumol (1996) shows that these societies struggled to offer entrepreneurs the incentives to turn technological inventions into innovation that would have benefited society, because the rules of the game favored alternative ways to pursue wealth. The main focus of the analysis is on incentives. While incentives clearly matter in inducing entrepreneurial action, so too do perceptions of those opportunities (Eliasson \& Henrekson, 2004).

Granted, the emergence of a knowledge filter sets incentives. For instance, entrepreneurs who pursue opportunities that successfully pass through the societal knowledge filter are more likely to assemble financial and human capital and are hence more likely to succeed and thrive. However, we suggest a somewhat different interpretation of the societal knowledge filter for entrepreneurship. We have argued that it creates a barrier to perceiving and pursuing opportunities for productive entrepreneurship. This distinction has important ramifications. While incentives can be reshaped by the entrepreneurial state, perceptions of entrepreneurial opportunities are more elusive and more stubborn. Indeed, the case of Singapore suggests that the actions of the entrepreneurial state continue to thicken the societal knowledge filter, reinforcing formidable barriers to endogenous growth.

In this regard, the economic policies of the Singaporean state serve as a warning to policymakers who embrace the ideas of the entrepreneurial state, not because they were unsuccessful, but because that success came with side effects, even the outstanding success of Singapore as part of the East Asian growth miracle has resulted in worrisome barriers impeding the transition to an entrepreneurial society.

Funding Open Access funding enabled and organized by CAUL and its Member Institutions.

Open Access This article is licensed under a Creative Commons Attribution 4.0 International License, which permits use, sharing, adaptation, distribution and reproduction in any medium or format, as long as you give appropriate credit to the original author(s) and the source, provide a link to the Creative Commons licence, and indicate if changes were made. The images or other third party material in this article are included in the article's Creative Commons licence, unless indicated otherwise in a credit line to the material. If material is not included in the article's Creative Commons licence and your intended use is not permitted by statutory regulation or exceeds the permitted use, you will need to obtain permission directly 
from the copyright holder. To view a copy of this licence, visit http://creativecommons.org/licenses/by/4.0/.

\section{References}

ADB Asia SME Monitor 2020 database. Data from Singapore Department of Statistics, Ministry of Trade and Industry.

Audretsch, D. B. (2021). Have we oversold the Silicon Valley model of entrepreneurship? Small Business Economics, 56, 849-856. https://doi.org/10.1007/s11187-019-00272-4

Audretsch, D. B. (2014). From the entrepreneurial university to the university for the entrepreneurial society. Journal of Technology Transfer, 39(3), 313-321. https://doi.org/10. 1007/s 10961-012-9288-1

Audretsch, D. B. (2007). The entrepreneurial society. Oxford University Presshttps://doi.org/10.1093/acprof:oso/97801 95183504.001.0001

Audretsch, D. B. (1995). Innovation and industry evolution. MIT Press.

Audretsch, D. B., Hülsbeck, M., \& Lehmann, E. E. (2012). Regional competitiveness, university spillovers, and entrepreneurial activity. Small Business Economics, 39(3), 587-601. https://doi.org/10.1007/s11187-011-9332-9

Bardhan, P. (1990). Symposium on the state and economic development. Journal of Economic Perspectives, 4(3), 3-7. http://www.jstor.org/stable/1942925

Baumol, W. J. (1996). Entrepreneurship: Productive, unproductive, and destructive. Journal of Business Venturing, 11(1), 3-22. https://doi.org/10.1016/0883-9026(94) 00014-X

Bedford, O., \& Chua, S. H. (2018). Everything also I want: An exploratory study of Singaporean Kiasuism (fear of losing out). Culture \& Psychology, 24(4), 491-511. https://doi. org/10.1177/1354067X17693831

Booth, A. (1999). Initial conditions and miraculous growth: Why is South East Asia different from Taiwan and South Korea? World Development, 27(2), 301-321. https://doi. org/10.1016/S0305-750X(98)00126-0

Braunerhjelm, P., Acs, Z. J., Audretsch, D. B., \& Carlsson, B. (2010). The missing link: Knowledge diffusion and entrepreneurship in endogenous growth. Small Business Economics, 34(2), 105-125. https://doi.org/10.1007/ s11187-009-9235-1

Bruton, G. D., Ahlstrom, D., \& Singh, K. (2002). The impact of the institutional environment on the venture capital industry in Singapore. Venture Capital, 4(3), 197-218. https://doi.org/10.1080/13691060213712

Carney, R. (2014). Singapore: Open state-led capitalism. In M. A. Witt \& G. Redding (Eds.), The Oxford handbook of Asian business systems (pp. 192-215). Oxford University Press. https://doi.org/10.1093/oxfordhb/9780199654925. 001.0001

Cheah, S., Ho, Y. P., \& Lim, P. (2016). Role of public science in fostering the innovation and startup ecosystem in Singapore. Asian Research Policy, 7(1), 78-93.

Choo, S. (2005). Developing an entrepreneurial culture in Singapore: Dream or reality. Asian Affairs, 36(3), 361-373. https://doi.org/10.1080/03068370500276332
Chua, H. S., \& Bedford, O. (2016). A qualitative exploration of fear of failure and entrepreneurial intent in Singapore. Journal of Career Development, 43(4), 319-334. https:// doi.org/10.1177/0894845315599255

Coughlan, S. (2016). Pisa tests: Singapore top in global education rankings. BBC. Retrieved December 27, 2021, from https://www.bbc.com/news/education-38212070

Cumming, D., Meoli, M., \& Vismara, S. (2021). Does equity crowdfunding democratize entrepreneurial finance? Small Business Economics, 56, 533-552.

Cumming, D. J., \& MacIntosh, J. G. (2006). Crowding out private equity: Canadian evidence. Journal of Business Venturing, 21(5), 569-609. https://doi.org/10.1007/s11187019-00188-z.10.1007/s11187-019-00188-z

Dahles, H. (2002). Transborder business: The "capital" input in Singapore enterprises venturing into ASEAN and beyond. SOJOURN: Journal of Social Issues in Southeast Asia, 17(2), 249-273. https://www.jstor.org/stable/41057088

Damrich, S., Kealey, T., \& Ricketts, M. (2022). Crowding in and crowding out within a contribution good model of research. Research Policy, 51(1). https://doi.org/10.1016/j. respol.2021.104400.

David, P. A., Hall, B. H., \& Toole, A. A. (2000). Is public R\&D a complement or substitute for private $R \& D$ ? A review of the econometric evidence. Research Policy, 29(4-5), 497529. https://doi.org/10.1016/S0048-7333(99)00087-6

Ebner, A. (2009). Entrepreneurial state: The Schumpeterian theory of industrial policy and the East Asian "miracle". In U. Cantner, J. L. Gaffard, \& L. Nesta (Eds.), Schumpeterian perspectives on innovation, competition and growth (pp. 369-390). Springer. https://doi.org/10.1007/978-3540-93777-7_20

EHL Insights. (2021). Singapore startup ecosystem: An entrepreneurs' paradise? Retrieved December 27, 2021, from https://hospitalityinsights.ehl.edu/bridging-valley-deathsingapore

Eliasson, G., \& Henrekson, M. (2004). William J. Baumol: An entrepreneurial economist on the economics of entrepreneurship. Small Business Economics, 23(1), 1-7. https:// doi.org/10.1023/B:SBEJ.0000026049.86377.df

Frankema, E., \& Smits, J. P. (2005). Exploring the historical roots of Eastern Asia's post-war catch-up growth: A trade perspective, 1906-1999. Journal of the Asia Pacific Economy, 10(2), 178-194. https://doi.org/10.1080/1354786050 0071410

Ghosh, B. C., Sock Kim, T., \& Meng, L. A. (1993). Factors contributing to the success of local SMEs-An insight from Singapore. Journal of Small Business and Entrepreneurship, 10(3), 33-46. https://doi.org/10.1080/08276331. 1993.10600426

Guellec, D., Pottelsberghe, V., \& de la Potterie, B. (2004). From R\&D to productivity growth: Do the institutional settings and the source of funds of R\&D matter? Oxford Bulletin of Economics and Statistics, 66(3), 353-378. https://doi.org/10.1111/j.1468-0084.2004.00083.x

Goel, R. K. (2018). Foreign direct investment and entrepreneurship: Gender differences across international economic freedom and taxation. Small Business Economics, 50(4), 887-897. https://doi.org/10.1007/s11187-017-9914-2

Gopinathan, S. L. M. H., \& Lee, M. H. (2011). Challenging and co-opting globalisation: Singapore's strategies in 
higher education. Journal of Higher Education Policy and Management, 33(3), 287-299. https://doi.org/10.1080/ 1360080X.2011.565001

He, T. (2020).Transforming the East Asian developmental state: Democratic mobilisation and the role of the middle class. Asian Journal of Comparative Politics, 2057891119897854https://doi.org/10.1177/2057891119 897854

Ho, Y. P., Ruan, Y., Hang, C. C., \& Wong, P. K. (2016). Technology upgrading of small-and-medium-sized enterprises (SMEs) through a manpower secondment strategy-A mixed-methods study of Singapore's T-Up program. Technovation, 57, 21-29. https://doi.org/10.1016/j.technovati on.2016.07.001

Ho, Y. P., Singh, A., \& Wong, P. K. (2010). National University of Singapore. In M. L. Fetters, P. G. Greene, M. P. Rice, \& J. S. Butler (Eds.), The development of universitybased entrepreneurship ecosystems: Global practices (pp. 149-176). Edward Elgar. https://doi.org/10.1080/14748 460.2011 .616329

Hooi, R., \& Wang, J. (2020). Research funding and academic engagement: A Singapore case. Knowledge Management Research \& Practice, 18(2), 162-174. https://doi.org/10. 1080/14778238.2019.1638739

Hu, G. A. (2004). Multinational corporations, patenting, and knowledge flow: The case of Singapore. Economic Development and Cultural Change, 52(4), 781-800. https://doi. org/10.1086/420902

Kam, H. W., \& Gopinathan, S. L. M. H. (1999). Recent developments in education in Singapore. School Effectiveness and School Improvement, 10(1), 99-117. https://doi.org/ 10.1076/sesi.10.1.99.3512

Kam, W. P., Ping, H. Y., \& Crystal, N. S. J. (2017). Growth dynamics of high-tech start-ups in Singapore: A longitudinal study. National University of Singapore.

Klingler-Vidra, R. (2018). Singapore: Financier and director. In R. Klingler-Vidra (Ed.), The venture capital state (pp. 93-108). Cornell University Press. https://doi.org/10. 1515/9781501723384-009

Klingler-Vidra, R. (2016). Diffusion and adaptation: Why even the Silicon Valley model is adapted as it diffuses to East Asia. Pacific Review, 29(5), 761-784. https://doi.org/10. 1080/09512748.2015.1022592

Kim, S. Y. (2012). Transitioning from fast follower to innovator: The institutional foundations of the Korean telecommunications sector. Review of International Political Economy, 19(1), 140-168. https://doi.org/10.1080/09692 290.2010.503125

Koh, A., \& Kong, E. (2021). Building growth enterprises in Singapore: Public-private partnership. In H. M. Chung \& K. Au (Eds.), Succession and innovation in Asia's smalland-medium-sized enterprises (pp. 201-242).

Kohli, A. (1994). Where do high growth political economies come from? The Japanese lineage of Korea's "developmental state." World Development, 22(9), 1269-1293. https://doi.org/10.1016/0305-750X(94)90004-3

Kolb, C., \& Wagner, M. (2015). Crowding in or crowding out: The link between academic entrepreneurship and entrepreneurial traits. Journal of Technology Transfer, 40(3), 387-408. https://doi.org/10.1007/s10961-014-9346-y
Low, L. (2005). Entrepreneurship development in Ireland and Singapore. Journal of the Asia Pacific Economy, 10(1), 116-138. https://doi.org/10.1080/1354786042000309107

Lu, Q., \& Hwang, P. (2010). The impact of liability of foreignness on international venture capital firms in Singapore. Asia Pacific Journal of Management, 27(1), 81-97. https://doi.org/10.1007/s10490-008-9125-0

Mathews, J. A. (2017). Dragon multinationals powered by linkage, leverage and learning: A review and development. Asia Pacific Journal of Management, 34(4), 769-775.

Mathews, J. A., Hu, M.-C., \& Wu, C.-Y. (2011). Fast-follower industrial dynamics: The case of Taiwan's emergent solar photovoltaic industry. Industry and Innovation, 18(2), 77-202. https://doi.org/10.1007/s10490-017-9543-y

Mazzucato, M. (2016). An entrepreneurial society needs an entrepreneurial state. Harvard Business Review. Retrieved December 27, 2021, from https://hbr.org/2016/10/an-entre preneurial-society-needs-an-entrepreneurial-state

Mazzucato, M. (2011). The entrepreneurial state. Demos, from: http://oro.open.ac.uk/30159/1/Entrepreneurial_ State_-_web.pdf.

Mazzucato, M. (2013). The entrepreneurial state: Debunking public vs. private myths in risk and innovation. Anthem Press.

Monetary Authority of Singapore (MAS). (2013). Reply to parliamentary question on SME loans. Question No 653, notice paper 424 of 2013. Retrieved December 27, 2021, from https://www.mas.gov.sg/news/parliamentary-replies/ 2013/reply-to-parliamentary-question-on-sme-loans

Monetary Authority of Singapore (MAS). (2003). Remaking the Singapore Economy, Keynote Address by Deputy Prime Minister Lee Hsien Loong at the Annual Dinner of the Economics Society of Singapore 8 April 2003, Retrieved December 30, 2021, from https://www.mas. gov.sg/news/speeches/2003/remaking-the-singaporeeconomy--keynote-address-by-dpm-lee-hsien-loong-atthe-annual-dinner-of-the-economics-society-of-singa pore--8-april-2003.

Morris, M. H., Neumeyer, X., \& Kuratko, D. F. (2015). A portfolio perspective on entrepreneurship and economic development. Small Business Economics, 45(4), 713-728. https://doi.org/10.1007/s11187-015-9678-5

$\mathrm{Ng}, \mathrm{P}$. T. (2012). The quest for innovation and entrepreneurship in Singapore: Strategies and challenges. Globalisation, Societies and Education, 10(3), 337-349. https://doi.org/ 10.1080/14767724.2012.710121

Pereira, A. A. (2008). Whither the developmental state? Explaining Singapore's continued developmentalism. Third World Quarterly, 29(6), 1189-1203. https://doi.org/ $10.1080 / 01436590802201162$

Porteous, C. (2020). Why entrepreneurs are launching their startups in Singapore. Retrieved December 27, 2021 from https://www.entrepreneur.com/article/347191

Prime Minister's Office Singapore. (2012). Speech by Prime Minister Lee Hsien Loong at the opening of the Campus for Research Excellence and Technological Enterprise (CREATE). Retrieved December 27, 2021, from https:// www.pmo.gov.sg/Newsroom/speech-prime-minister-leehsien-loong-opening-campus-research-excellence-and

Prime, P. B. (2012). Utilizing FDI to stay ahead: The case of Singapore. Studies in Comparative International 
Development, 47(2), 139-160. https://doi.org/10.1007/ s12116-012-9113-8

Quek, C. (2016). Why many Singapore entrepreneurs fail to think big. TECHINASIA. Retrieved December 27, 2021, from https://www.techinasia.com/talk/singapore-entre preneurs-fail-big

Randstad Monitor. (2017). MNCs still employers of choice in Singapore, Hong Kong SAR and Malaysia. Randstad. Retrieved December 27, 2021, from https://www.randstad. com.sg/about-us/news/mncs-still-employers-of-choice-insingapore-hong-kong-and-malaysia/

Scott, A. (2015). How Singapore became an entrepreneurial hub. Harvard Business Review. Retrieved December 27, 2021, from https://hbr.org/2015/02/how-singaporebecame-an-entrepreneurial-hub

Shane, S. (2009). Why encouraging more people to become entrepreneurs is bad public policy. Small Business Economics, 33(2), 141-149.

Shane, S., \& Venkataraman, S. (2000). The promise of entrepreneurship as a field of research. Academy of Management Review, 25(1), 217-226. https://doi.org/10.1007/ s11187-009-9215-5

Singapore Government. (2002, February 5). An entrepreneurial culture for Singapore [Press release]. Retrieved December 27, 2021, from https://www.smu.edu.sg/sites/default/files/ microsites/hrh/pdf/SGP_20020205_MM-Lee-Speech.pdf

Startup Genome (2020). The global startup ecosystem report GSER 2020: The new normal or the global startup economy and the impact of COVID-19. Retrieved December 27, 2021, from https://www.andeglobal. org/publication/the-global-startup-ecosystem-report2020-the-new-normal-for-the-global-startup-econo my-and-the-impact-of-covid-19/

Tan, K. C. D., Teo, T. W., \& Poon, C. L. (2016). Singapore science education. In M. H. Chu (Ed.), Science Education Research and Practice in Asia (pp. 155-174). Springer. https://doi.org/10.1007/978-981-10-0847-4

Tegos, M. (2015). Report: Singapore is the $10^{\text {th }}$ best startup ecosystem in the world, but it lacks talent. TECHINASIA. Retrieved December 27, 2021, from https://www.techi nasia.com/compass-startup-ecosystem-ranking-report2015-singapore

Teo, H. A., \& Poon, J. T. F. (1994). Career choice of undergraduates and SMEs in Singapore. International Journal of Career Management, 6(3), 20-26. https://doi.org/10. $1108 / 09556219410062613$

Vivian. (2021). The full list of unicorn startups in Southeast Asia. Next Unicorn. Retrieved from https://nextu nicorn.ventures/the-full-list-of-unicorn-startups-in-south east-asia/

Wang, C. K., \& Ang, B. L. (2004). Determinants of venture performance in Singapore. Journal of Small Business Management, 42(4), 347-363. https://doi.org/10.1111/j. 1540-627X.2004.00116.x
Wang, J. (2018). Innovation and government intervention: A comparison of Singapore and Hong Kong. Research Policy, 47(2), 399-412. https://doi.org/10.1016/j.respol.2017. 12.008

Welter, F. (2011). Contextualizing entrepreneurship-Conceptual challenges and ways forward. Entrepreneurship Theory and Practice, 35(1), 165-184. https://doi.org/10. 1111/j.1540-6520.2010.00427.x

Wong, J. (2011). Betting on biotech book: Innovation and the limits of Asia's developmental state. Cornell University Presshttps://doi.org/10.7591/9780801463372

Wong, P. K. (2001). Leveraging multinational corporations, fostering technopreneurship: The changing role of S\&T policy in Singapore. International Journal of Technology Management, 22(5/6), 539-567. https://doi.org/10.1504/ IJTM.2001.002977

Wong, P. K., Foo, M. D., \& Wong, F. (2001). Global Entrepreneurship Monitor Singapore country report 2000. National University of Singapore.

Wong, P. K., \& Ho, Y. P. (2007a). Characteristics and determinants of informal investment in Singapore. Venture Capital, 9(1), 43-70. https://doi.org/10.1080/1369106060 0996772

Wong, P. K., \& Ho, Y. P. (2007b). Knowledge sources of innovation in a small open economy: The case of Singapore. Scientometrics, 70(2), 223-249. https://doi.org/10.1007/ s11192-007-0201-x

Wong, P. K., Ho, Y. P., \& Singh, A. (2010). Industrial cluster development and innovation in Singapore. In A. Kuchiki \& M. Tsuji (Eds.), From agglomeration to innovation (pp. 50-116). Palgrave Macmillan.

Wonglimpiyarat, J. (2013). The role of equity financing to support entrepreneurship in Asia-The experience of Singapore and Thailand. Technovation, 33(4-5), 163-171. https://doi.org/10.1016/j.technovation.2012.12.004

World Bank. (1993). The East Asian miracle: Economic growth and public policy. Oxford University Presshttps://doi.org/ 10.2307/2058969

World Bank. (2021). Research and development expenditure (\% of GDP)—Singapore. Retrieved December 27, 2021, from https://data.worldbank.org/indicator/GB.XPD.RSDV.GD. ZS?locations $=$ SG

Yeung, H. W. C. (2000). State intervention and neoliberalism in the globalizing world economy: Lessons from Singapore's regionalization programme. Pacific Review, 13(1), 133-162. https://doi.org/10.1080/095127400363677

Yu, T. F. (1997). Entrepreneurial state: The role of government in the economic development of the Asian newly industrializing economies. Development Policy Review, 15(1), 47-64. https://doi.org/10.1111/1467-7679.00025

Publisher's Note Springer Nature remains neutral with regard to jurisdictional claims in published maps and institutional affiliations. 